\title{
PROJETO EMANCIPATÓRIO MODERNO: CONSTRUÇÃO, DESCONSTRUÇÃO E RECONSTRUÇÃO ${ }^{1}$
}

\author{
Modern emancipatory project: construction, deconstruction and reconstruction
}

\author{
Vicente Zatti \\ IFRS - Campus Canoas
}

\begin{abstract}
Resumo: O projeto emancipatório moderno estabelece uma concepção otimista de desenvolvimento científico e social. Os filósofos Immanuel Kant e Karl Marx, de modo distinto, levam ao ápice tal projeto emancipatório, o primeiro, ancorado numa concepção de sujeito transcendental capaz de estabelecer verdade e validade universal, o segundo, ancorado na categoria de trabalho desenvolvida em sua doutrina do materialismo histórico. A partir do século XIX, filósofos como Nietzsche, Heidegger e Adorno/Horkheimer põem sob suspeita tal projeto ao demonstrar seus fundamentos não metafísicos. Tais críticas expurgam as pretensões totalitárias do projeto emancipatório moderno, e nos remetem à sua revisão. O filósofo alemão Jurgen Habermas, considerando as críticas elaboradas pelos filósofos da suspeita, vai buscar reconstruir o projeto emancipatório moderno a partir de bases pós-metafísicas. A raiz de tal reconstrução está em Trabalho e Interação. Notas sobre a filosofia do espírito de Hegel em Jena, na qual Habermas promove o confronto da filosofia hegeliana com o pensamento de Kant e Marx, possibilitando a revisão destes. Nessa revisão Habermas desenvolve os conceitos de trabalho e interação, que ao mesmo tempo fundamentam sua crítica à tecnocracia e lançam os pilares para a posterior elaboração da Teoria da Ação Comunicativa.
\end{abstract}

Palavras-chave: Modernidade; Emancipação; Técnica e Ciência; Desconstrução; Reconstrução.

Abstract: The modern emancipatory project establishes one optimism conception of the scientific and social development. The philosophers Immanuel Kant and Karl Marx of a distinctive way, carry the emancipator project at his height, the first, anchored in a transcendental subject conception able to establish truth and universal validity, the second, anchored in the work category developed in his doctrine of historical materialism. After the XIX century, philosophers like Nietzsche, Heidegger and Adorno/Horkheimer put in suspect this project when demonstrate their not metaphysic fundaments. Such critics expunge the totalitarian pretensions of the modern emancipatory project and remit us their revision. The German philosopher Jurgen Habermas, considering the elaborated critics for philosophers of the suspect. Will search to reconstruct the modern emancipatory from the bases after-metaphysics. The root of this reconstruction is in the Work and Interaction. Quotes about Hegel's philosophy of spirit in Jena, Habermas promotes the confrontation of the Hegelian philosophy with the thoughts of Kant and

${ }^{1} \mathrm{O}$ presente artigo resultou de pesquisa realizada no Programa de Pós-graduação em Educação da Universidade Federal do Rio Grande do Sul, cuja tese de doutorado foi defendida em 2012. Uma versão inicial e incompleta da menor parte deste trabalho foi publicado com o título Projeto educacional emancipatório moderno e a crise do esclarecimento, na Revista Vértices (Campos dos Goitacazes), v. 14, p. 93-116, 2012. 
Marx, possibiliting the revision of these. In these revisions Habermas developed the concept of work and interaction, which at the same time fundament your critics to the technocracy and launch the pillar for the elaboration posterior of the Theory of Communicative Action.

Keywords: Modernity; Emancipation; Technical and Science; Desconstruction; Reconstruction.

\section{Introdução}

A modernidade é um período histórico de difícil delimitação. Em termos gerais podemos dizer que iniciou no século XVI com a descoberta do novo mundo, com o Renascimento, com a Reforma Protestante, e chegou ao seu auge no final do século XVIII. Para nós o essencial é definir o conjunto de ideias que compõe o movimento que chamamos modernidade. Nesse aspecto, segundo Habermas (2002), Weber a diagnostica como o período passou a estabelecer uma relação essencial com a racionalidade. Mas para Habermas (2002, p. 9), foi Hegel quem pela primeira vez tomou consciência da relação interna entre modernidade e racionalidade ao denominar a modernidade como novos tempos ou tempos modernos e caracterizá-los pela expectativa positiva estabelecida em relação ao futuro. Essa expectativa do novo tempo anuncia a ruptura com o passado e a aurora do esclarecimento. "O novo tempo é o tempo da revolução, da emancipação, do progresso, do desenvolvimento, da crise, do espírito do tempo, do domínio pleno da razão."(MÜHL, 2003, p. 112). O homem busca libertar-se de toda e qualquer obediência e dependência que não seja a da autofundamentação racional.

Segundo Prestes (1996, p. 17) as origens da racionalidade moderna remontam ao empirismo e ao racionalismo do século XVI, cujos principais representantes foram, respectivamente, Bacon e Descartes. O empirismo de Bacon lança os fundamentos da ciência moderna ao pensar que a racionalidade com aplicação científica pode chegar a resolver problemas por meio do controle e da previsão dos eventos naturais. Sua proposta de conhecimento está alicerçada em uma visão prática e utilitária, segundo a qual o conhecimento pode transformar de forma concreta para melhor a vida humana e, seu critério de avaliação deve ser justamente os resultados efetivos. Nessa concepção o conhecimento é um instrumental de poder e sua legitimidade está em 
proporcionar ao homem o domínio e manipulação da natureza, além de possibilitar a organização da sociedade de acordo com parâmetros científicos. O racionalismo de Descartes busca não apenas tematizar a natureza mas também tematiza a validade do conhecer. Por meio da elaboração e aplicação do método científico chega à verdade fundamental do Penso, logo existo, o que estabelece o pensamento como ponto de partida da verdade e seu critério supremo. Em outras palavras, estabelece a subjetividade como instância de fundamentação do conhecimento. É o advento da metafísica da subjetividade, que estenderá seus desdobramentos em Kant. Segundo Martini $(2009$, p. 19) para Habermas podemos concordar com Hegel e afirmar que a filosofia moderna começa com Descartes quando o Discurso do método critica a metafísica tradicional e estabelece o eu pensante como o novo fundamento.

Apesar de possuírem pensamentos que em muitos aspectos se contrapõe, Bacon e Descartes fundam uma concepção de razão todo-poderosa capaz de conduzir à verdade e ao progresso da humanidade. Toda e qualquer legitimidade de verdade está ligada a uma concepção empírico-matemática que busca a objetivação do mundo através de procedimentos racionais demonstrativos, matemáticos, quantitativos. Segundo Mühl (2003, p. 115) em ambos os autores a razão, como medida de todas as coisas, não tem um estatuto apenas lógico, mas axiológico, que se expressa no reconhecimento do homem como valor, a partir de sua condição racional. Dessa forma em ambos, conhecimento e emancipação estão atrelados pois são produzidos por uma subjetividade que tem o poder de dominar a natureza e estabelecer o sentido da realidade. A razão possui os meios adequados para estabelecer os fins, tornando-se fator de progresso e felicidade. Em Bacon e Descartes a realização racional levaria a humanidade ao progresso científico e moral por meio da expansão do modelo de racionalidade a todos os domínios do saber. 
Para Giacoia Junior (2005, p. 136), esses pioneiros da Aufklärung ${ }^{2}$ possuíam na base de seu credo científico um otimismo triunfalista: a razão, pela ciência e técnica, pode enfrentar e resolver os problemas humanos, de modo a garantir o domínio sobre as forças da natureza e realizar a justiça nas relações entre os homens. Para Prestes (1996, p. 19), “a modernidade que nasce com o iluminismo, no século XVIII, apoia-se justamente na possibilidade da razão de enunciar verdades universais, de entender e dominar o mundo, superar os mitos e as forças mágicas, de forma a emancipar o homem". Vejamos como tal ideário emancipatório aparece no pensamento dos filósofos da modernidade Immanuel Kant e Karl Marx. Em seguida, nos deteremos na crítica estabelecida por Nietzsche, Heidegger e a Escola de Frankfurt, em especial Adorno e Horkheimer. Por fim analisaremos a revisão do pensamento de Kant e Marx que Habermas realiza em Trabalho e Interação. Notas sobre a filosofia do espírito de Hegel em Jena, o que lança os fundamentos para o filósofo alemão propor a reconstrução do projeto emancipatório moderno.

\section{Immanuel Kant e o Ideário Emancipatório da Modernidade}

Immanuel Kant fundamenta seu ideário emancipatório na ideia de que a razão é capaz de enunciar princípios com validade universal. A compreensão de tal questão envolve a inserção no debate kantiano sobre o racionalismo e empirismo. Kant não podia concordar com os racionalistas que por meio das noções a priori do espírito, as ideias inatas, pretendiam atingir verdades absolutas e constituir uma metafísica, mas também não concordava com os empiristas que não admitiam a possibilidade de a razão pensar a priori e estabelecer conhecimentos com validade universal e necessária. Então Kant interroga-se sobre as possibilidades da razão e chega ao que se denomina Revolução Copernicana de Kant: o fundamento do conhecimento não é a natureza, mas o sujeito com suas leis da sensibilidade e do intelecto. Só conhecemos das coisas aquilo que nós mesmos colocamos a priori nelas. Para Kant há uma

\footnotetext{
${ }^{2}$ Nenhum termo português oferece equivalência satisfatória ao termo alemão Aufklärung. As traduções mais freqüentes são: iluminismo, ilustração, filosofia das luzes, época das luzes, esclarecimento.
} 
capacidade originária da razão e o sujeito impõe ao mundo suas condições de compreensão.

Para Messer (1946, p. 342) o sentido da revolução copernicana consiste em ter Kant acabado com o predomínio absoluto do pensamento físico e da filosofia naturalista. A libertação do naturalismo iluminista que impunha uma necessidade natural onipotente e não deixava lugar genuíno para a liberdade, consiste na descoberta de que o objeto considerado pela física, a natureza, não é a realidade absoluta. Assim, a natureza não é mais considerada coisa em si, mas sim o sistema regular daquilo que o eu se representa. O eu se torna o Sol em torno do qual os objetos giram. Ainda segundo Messer (1946), Kant não teria realizado tal revolução se seu pensamento não se achasse tão profundamente enraizado na sua consciência moral, se não tivesse levado em conta a vontade que se determina a si própria e a lei que a vontade impõe a si própria, ou seja, se não estivesse enraizado em sua concepção de autonomia moral. Kant manteve a leitura empírica e matemática da natureza que era corrente desde Galileu, mas a manteve restrita à natureza, não a aplicando ao homem. Quanto ao homem, Kant o pensou como dotado de uma razão com o poder de pensar o universal, vinculando a isso, sua liberdade e dignidade, sua autonomia.

Na Crítica da Razão Pura, Kant demonstrou a possibilidade das ciências matemáticas e naturais e acabou chegando à negação de uma metafísica que se apoia na mesma objetividade e universalidade dessas ciências. A razão teórica ficaria limitada ao âmbito da experiência. Só podemos conhecer os fenômenos que nos são acessíveis pelos sentidos; liberdade, imortalidade da alma e Deus, temas da metafísica, não são objetos de conhecimento. O progresso humano no campo especulativo não significa o progresso moral do homem. A partir da impossibilidade da metafísica enquanto conhecimento, Kant precisa construir uma crítica para conhecer as possibilidades que a razão dispõe para elaborar uma metafísica. Na Crítica da Razão Prática, Kant demonstra que a razão pura é prática por si mesma, ou seja, ela dá a lei 
que alicerça a moralidade, a razão fornece as leis práticas que guiam a vontade. Leis práticas são princípios práticos objetivos, regras válidas para todo ser racional. Elas se diferenciam das máximas que são princípios práticos subjetivos, regras que o sujeito considera como válidas apenas para sua própria vontade. "Admitindo-se que a razão pura possa encerrar em si um fundamento prático, suficiente para a determinação da vontade, então há leis práticas, mas se não se admite o mesmo, então todos os princípios práticos serão meras máximas" (KANT, sd, p. 31).

Segundo Zatti (2007), para Kant, se os desejos, os impulsos, impressões, ou qualquer objeto da faculdade de desejar forem condições para o princípio da regra prática, então o princípio será empírico, não será lei prática, não haverá unidade nem incondicionalidade do agir, e assim, não garantirá a autonomia. A lei moral deve independer da experiência. Uma vontade boa determina-se a si mesma, independentemente de qualquer causalidade empírica, sem preocupar-se com prazer ou dor que a ação possa provocar. Somente a razão, determinando por si mesma a vontade, é uma verdadeira faculdade superior de desejar. "Um ser racional não deve conceber as suas máximas como leis práticas universais, podendo apenas concebê-las como princípios que determinam o fundamento da vontade, não segundo a matéria, mas sim pela forma" (KANT, sd, p.37). Um ser racional não pode conceber seus princípios subjetivos práticos, suas máximas, como leis universais. A vontade para ser moral não deve determinar-se pelo objeto, deverá abstrair a matéria da lei para reterIhe apenas a forma, a universalidade.

Em suma: ou um ser racional não pode conceber os seus princípios subjetivamente práticos, isto é, as suas máximas como sendo ao mesmo tempo leis universais ou, de forma inversa, deve admitir que a simples forma dos mesmos, segundo a qual se capacitam eles para uma legislação universal, reveste esta de característico conveniente e apropriado. (KANT, sd, p.37).

Dessa forma, para Kant a vontade só pode ser determinada pela simples forma legislativa das máximas. A mera forma da lei só pode ser representada pela razão e não pelas leis naturais que regem os fenômenos. A vontade deve ser 
independente da lei natural dos fenômenos, e essa independência se denomina liberdade. Então, a vontade que tem como lei a mera forma legisladora das máximas é uma vontade livre. "A razão pura é por si mesma prática, facultando (ao homem) uma lei universal que denominamos lei moral" (KANT, sd, p. 41). A força da lei moral está em sua absoluta necessidade e em sua universalidade. A universalidade da lei moral, para Kant, significa que ela tem de valer para todos os seres racionais em geral. Em Kant, universalidade significa racionalidade. Já a absoluta necessidade denota uma necessidade que não seja condicionada a nenhum outro fim, mas que seja necessária por si mesma. Por isso a lei moral deve ser um mandamento, um imperativo, que seja categórico e não hipotético. Em virtude de ser incondicional e universal, o imperativo categórico possui apenas conteúdo formal, sendo portanto, uma fórmula. A lei moral deve ser assim formulada, em termos de imperativo categórico: "Age de tal forma que a máxima de tua vontade possa valer-te sempre como princípio de uma legislação universal" (KANT, sd, p. 40). Segundo Kant, nós temos consciência imediata dessa lei, ela se impõe como um fato, um fato da razão. Mas não é um fato empírico, é o único fato da razão pura que se manifesta como originariamente legisladora, impõe-se a nós de forma a priori.

Para Kant tudo que há na natureza se conforma com suas leis, exceto o homem. Isso porque o homem, na condição de ser racional, conforma-se às leis universais que ele próprio formula. Por isso os seres racionais são autônomos e têm uma dignidade particular, se destacam da natureza por serem livres e autodeterminantes. (cf. TAYLOR, 1997, p. 467). Esse status racional nos impõe a obrigação de viver como agente racional. A natureza racional é a única coisa que existe como um fim em si mesmo. Esse status de reivindicação de responsabilidade total ao homem aparece de forma clara quando Kant define que é Aufklärung:

Esclarecimento [Aufklärung] é a saída do homem de sua menoridade, da qual ele próprio é culpado. A menoridade é a incapacidade de fazer uso de seu entendimento sem a direção de outro indivíduo. O homem é o próprio culpado dessa menoridade se a causa dela não se encontra na falta de 
entendimento, mas na falta de decisão e coragem de servir-se de si mesmo sem a direção de outrem. Sapere aude! Tem coragem de fazer uso de teu próprio entendimento, tal é o lema do esclarecimento [Aufklärung]" (KANT, 2005b, p. 63-64).

Essa citação de Kant expressa com muita força o ideal de homem emancipado que a modernidade funda. O Aufklärung significa mais que conhecer simplesmente, acima de tudo, significa a realização de sua filosofia prática, que busca a moralização da ação humana através de um processo racional. Segundo Rouanet $(1987$, p. 209) o lema Sapere aude (ouse saber) refere-se à razão em seu sentido mais amplo, não exclusivamente à razão científica. O Aufklärung implica na superação da menoridade, requer a decisão e a coragem de servir-se de si mesmo, ou seja, de servir-se de sua própria razão para pensar por conta própria, e guiar-se sem a direção de outro indivíduo. Segundo Mühl (2005, p. 309), o princípio fundamental da pedagogia kantiana está relacionado à palavra Aufklärung, o esclarecimento, dado pelas luzes da razão, "possibilita o indivíduo abandonar a ignorância, permitindo sua ascensão a um nível superior de cultura, educação e formação" (idem). Kant alerta que é difícil para um homem desvencilhar-se da menoridade quando ela se tornou para ele quase uma natureza, mesmo assim, para que tal ocorra, nada mais se exige a não ser liberdade de fazer uso público da razão em todas as questões. Kant (2005, p.66) entende como uso público da razão aquele que qualquer homem, enquanto sábio, faz dela diante do grande público letrado, todavia, entende como uso privado aquele que qualquer homem pode fazer de sua razão em um cargo público ou função a ele confiado. A liberdade de fazer uso público da razão é necessária para que se possa pensar por conta própria, ou seja, segundo a própria razão.

Segundo Larrosa (2005, p. 86-87), Kant com a definição de Aufklärung acima citada, estabelece um conceito de liberdade com duas faces. De um lado a liberdade é libertação de qualquer tipo de tutela e exige coragem, esforço. É a face na qual o sujeito aparece como protagonista de uma luta pela libertação. Por outro lado a liberdade é algo que se tem na forma de autonomia. A liberdade é a autonomia da vontade, a autonomia da razão prática, ou seja, capacidade de o homem, individual ou 
coletivamente, dar a si mesmo sua própria lei. É livre o indivíduo que se submete obedientemente à própria lei. É uma forma de autogoverno cuja não arbitrariedade está garantida pela razão. É nisso onde se reconhece a maioridade: um sujeito é livre quando se guia por princípios racionais. Dessa forma, um homem se torna maior, emancipado, quando se liberta de tudo o que se lhe impõe como heteronomia e quando se torna capaz de seguir sua própria lei.

\section{Karl Marx e a Emancipação ${ }^{3}$}

Em Marx a emancipação deixa de ser uma categoria que se refere ao sujeito autônomo e passa a estar relacionada à categoria de trabalho. Segundo Flickinger (1992, p. 499), o termo emancipação em Marx não tem mais a ver com o encanto do sujeito liberal burguês enraizado na velha ideia de subjetividade, ou seja, no indivíduo autônomo e senhor de si mesmo. Para compreendermos o que Marx entende por emancipação, precisamos compreender sua categoria de trabalho e as deformações sociais nela incluídas. Para Saviani (2004, p. 71), quando Marx procura entender em que consiste a natureza humana, a resposta formulada é o trabalho. O conteúdo da essência humana consiste no trabalho, o ser do homem, não é dado pela natureza mas produzido pelos próprios homens. Diferentemente dos outros animais que possuem a existência garantida pela natureza, bastando a adaptação para garantir a sobrevivência, o homem necessita agir sobre a natureza, transformando-a e adaptando-a às suas necessidades. Esse ato de agir sobre a natureza transformando-a

\footnotetext{
${ }^{3}$ Utilizamos nesse item especialmente $A$ ideologia Alemã e Teses sobre Feuerbach, pois nessas obras "[...] o conceito de essência humana passa a coincidir com a práxis, ou seja, o homem passa a ser entendido como ser prático, produtor, transformador. Em consequência, o conceito de alienação deixa de desempenhar o papel central que desempenhava nos Manuscritos. Em lugar de ser o fundamento explicativo da situação humana, passa a ser considerado como um fenômeno social, que, por sua vez, é fundamentado e explicado por outro fenômeno histórico, a saber, a divisão do trabalho." (SAVIANI, 2004, p. 78-79).
} 
é que em Marx aparece como a categoria de trabalho. Assim Marx constrói a base de sua concepção materialista da história4:

\begin{abstract}
"Podemos distinguir os homens dos animais pela consciência, pela religião, por tudo o que se quiser. Mas eles começam a distinguir-se dos animais assim que começam a produzir os seus meios de vida [...]. Ao produzirem os seus meios de vida, os homens produzem indiretamente a sua própria vida material. [...]. Aquilo que eles são, coincide, portanto, com a sua produção, com o que produzem e também com o como produzem. Aquilo que os indivíduos são, depende, portanto, das condições materiais da sua produção."(MARX; ENGELS, 1984, p. 15).
\end{abstract}

Para Marx e Engels (1984, p. 22), a produção das ideias e representações da consciência estão diretamente entrelaçados com a atividade material dos homens. Os homens desenvolvem a sua produção material e, no seu intercâmbio material, ao mudarem essa realidade, mudam também seu pensamento. "Não é a consciência que determina a vida, é a vida que determina a consciência."(MARX; ENGELS, 1984, p. 23). Essa concepção antropológica segundo a qual o homem se constitui enquanto tal e constitui a própria consciência através do trabalho, é o pressuposto a partir do qual Marx desenvolve sua concepção materialista de história. Sendo a consciência o resultado das relações materiais dos homens com o mundo e entre si, a transformação da sociedade não é uma questão que se refere à consciência, mas sim à transformação concreta da realidade. "A libertação é um ato histórico, não um ato de pensamento, e é efetuada por relações históricas, pelo nível da indústria, do comércio, da agricultura, do intercâmbio [...]"(MARX; ENGELS, 1984, p. 25).

A concepção antropológica de Marx, pressuposto do materialismo histórico, estabelece o trabalho como constituidor do homem, mas aqui se trata do trabalho

\footnotetext{
${ }^{4}$ Segundo Abbagnano (1962, p. 624) o materialismo histórico é o cânon de interpretação histórica proposto por Marx e consiste em reconhecer os fatores econômicos (relações de trabalho e produção) como elementos preponderantes na determinação dos acontecimentos históricos. O pressuposto dessa concepção é o ponto de vista antropológico de Marx segundo o qual a personalidade humana é constituída intrinsecamente por relações de trabalho e produção que o homem entra para fazer frente à suas necessidades. A consciência do homem é um resultado dessas relações e não seu pressuposto. Marx elaborou esta teoria em oposição à Hegel, para este, é a consciência que determina o ser social do homem.
} 
entendido como trabalho social. É o que podemos ver na citação abaixo sobre linguagem e consciência:

\begin{abstract}
A linguagem é tão velha quanto a consciência - a linguagem é a consciência real prática que existe também para outros homens e que, portanto, só assim existe também para mim, e a linguagem só nasce como a consciência, da necessidade, da carência física do intercâmbio com outros homens. [...] A consciência é, pois, logo desde o começo, um produto social, e continuará a sê-lo enquanto existirem homens. (MARX; ENGELS, 1984, p. 34).
\end{abstract}

Mas, se o trabalho é trabalho social como Marx explica o fenômeno da desigualdade social, ou, desigualdade na divisão dos produtos do trabalho? De acordo com Marx e Engels (1984, p. 35) é a divisão do trabalho que dá origem à repartição desigual do trabalho social. Para eles tal divisão do trabalho só se torna realmente divisão a partir da divisão entre trabalho material e intelectual. A maior divisão entre trabalho material e intelectual é a separação da cidade com o campo. A partir de tal divisão que surge o trabalho coercitivo no qual está presente a exploração do trabalhador. Segundo Sarup (1980, p. 109), para Marx, o trabalho é coercitivo não devido à sua natureza, mas às condições históricas em que ele é realizado. No capitalismo, a produção é realizada em circunstâncias tão alienadoras que o trabalho, a atividade criativa do homem, se torna um processo de desumanização. No capitalismo os objetos, produtos da atividade auto-realizadora e criativa do trabalhador, Ihe são tomados. Ele não consegue ser dono do produto do seu trabalho, que se torna hostil e alheio a ele. "No trabalho alienado interrompe-se o ciclo da exteriorização e da apropriação das forças essenciais objetivadas. O produtor é separado da fruição de seus produtos, nos quais podia reencontrar-se a si mesmo e, com isso, aliena-se de si mesmo."(HABERMAS, 2002, p. 92). Essa alienação do homem em relação a seu produto também implica em alienação na relação entre os homens na medida em que no capitalismo o trabalho se torna uma mercadoria. Desse modo, o trabalho se torna não a satisfação de uma necessidade, mas um meio de satisfação de outras necessidades; a vida do trabalhador se torna apenas meio para ele existir. Ou 
seja, o sujeito humano se transforma no objeto de seus próprios produtos. Ao contrário de Feuerbach, para Marx a alienação não é algo decorrente de uma essência humana universal e abstrata, ela é uma forma concreta do trabalho humano que está condicionado historicamente. Desse modo, Marx e Engels nas Teses sobre Feuerbach estabelecem a relação entre materialismo e práxis: "A insuficiência principal de todo o materialismo até os nossos dias (o de Feuerbach incluído) é a de a coisa, a realidade, o mundo sensível, serem tomados sob a forma do objeto ou da contemplação; mas não como atividade humana sensível, práxis". (MARX; ENGELS, 1984, p. 107). Marx e Engels (1984, p. 108), estabelecem a práxis ${ }^{5}$ revolucionária como a possibilidade para a mudança das circunstâncias e para a autotransformação. Desse modo, a emancipação está relacionada necessariamente à práxis.

Segundo Canielles e Oliveira (2011, p. 6-7), Marx estabelece uma diferenciação entre emancipação política e emancipação humana. A emancipação política representa um grande progresso mas não é a ultima etapa da emancipação humana em geral. A emancipação política representa a emancipação da sociedade civil. Dentro de um ordenamento capitalista, a emancipação política é o máximo a que se pode aspirar e a emancipação humana só é possível em um novo ordenamento social. Por exemplo, com a emancipação política é possível conseguir liberdade religiosa o que não liberta o homem da religião, é possível conseguir liberdade de propriedade, o que não liberta o homem da propriedade e do egoísmo gerado pela ambição de seu acúmulo. No contexto marxiano, a emancipação só poderá ser

\footnotetext{
${ }^{5}$ A práxis revolucionária em Marx está relacionada à transformação concreta das estruturas sociais de exploração: "A transformação da teoria, isto é, sua transformação de utopia (ou ideologia) em ciência, é condição indispensável da práxis revolucionária. [...] Trata-se não de criar a consciência de um fato existente, mas, sim, de derrubar o que existe, de transformar as coisas."(VÁZQUEZ, 2011, p. 155).

"A necessidade da práxis revolucionária que conduz a essa solução não surge de uma contradição entre a história e a verdadeira essência humana, mas, sim, de uma contradição entre as forças produtivas e as relações de produção. O proletariado não é agora o ser que encarna o sofrimento humano universal, ou o trabalhador que nega sua essência humana no trabalho, mas sim, antes de tudo, o membro de uma classe social que, pelo lugar que ocupa na produção, e por estar vinculado à forma mais avançada de produção, entra em conflito com a classe dominante e, ao adquirir a consciência da necessidade da revolução, leva-a a cabo para abolir o domínio de todas as classes, abolindo as próprias classes."(VÁZQUEZ, 2011, p. 157-158).
} 
concretizada com a superação do sistema do capital, e ninguém alcança esse objetivo na individualidade, pois é um processo coletivo e social. A emancipação humana está no horizonte de toda a produção de Marx, é o principio pelo qual haveria a possibilidade de rompimento e superação do modelo social do capital e a possibilidade de instauração de um novo modelo social que acabaria com a dualidade do homem na sociedade. Ou seja, a emancipação humana só é possível quando o homem individual for superado e, coletivamente, determinar-se como ser genérico. "Para isso, é necessária uma nova consciência política e social, e isto, exigiria uma formação integral do Homem e de suas potencialidades - através da Educação e do Trabalho". (CANIELLES; OLIVEIRA, 2011, p. 7). Para Marx a emancipação possui um caráter único só é possível através da superação do sistema do capital.

\section{Nietzsche e Heidegger: Projeto Emancipatório Moderno Sob Suspeita}

O projeto emancipatório moderno possui suas raízes especialmente em Kant e Marx, e é posto sob suspeita especialmente com Nietzsche, Heidegger e pensadores da Escola de Frankfurt. Para Habermas (2002, p.80) há em comum entre os pensadores/filósofos da suspeita a acusação contra uma razão fundada no princípio da subjetividade. Para eles a razão só denuncia a opressão, degradação, exploração e alienação, para implantar em seu lugar a dominação implacável de sua racionalidade. "Uma vez que esse regime de subjetividade dilatada em falso absoluto transforma os meios da conscientização e da emancipação em outros tantos instrumentos da objetivação e do controle, ele se proporciona uma imunidade sinistra nas formas da dominação oculta". (Habermas 2002, p. 80).

Para Habermas (2002) Nietzsche é o ponto de viragem, ou placa giratória, que altera a direção da trajetória anteriormente seguida pelo discurso filosófico da modernidade. Essa virada representa a opção por uma crítica radical à razão, renunciando a uma nova revisão do conceito de razão, e uma postura contrária ao 
projeto da modernidade, desacreditando na razão como recurso capaz de promover a emancipação humana.

Trata-se agora de um total abandono da modernidade esvaziada pelo niilismo. Com Nietzsche, a crítica da modernidade renuncia, pela primeira vez, a reter seu conteúdo emancipador. A razão centrada no sujeito é confrontada com o absolutamente outro da razão. E, enquanto instância contrária à razão, Nietzsche invoca as experiências de autodesvelamento, transferidas ao arcaico, de uma subjetividade descentrada e liberta de todas as limitações da cognição e da atividade com respeito a fins, de todos os imperativos da utilidade e da moral. A ruptura com o princípio da 'individuação' torna-se a via para escapar da modernidade. (HABERMAS, 2002, p. 137).

O projeto moderno, como elaborado especialmente por Kant, centrava a emancipação na ideia de sujeito, que pela razão chegaria à ação moral e intelectual esclarecidas. E o projeto pedagógico moderno funda-se na metafísica de subjetividade, aspira à universalidade e pressupõe a ideia de aperfeiçoamento moral, de emancipação, crê no sentido e no aperfeiçoamento histórico. Segundo Hermann (2001, p. 89) o pensamento de Nietzsche é uma das críticas mais profundas da ideia de ética universal, base para o projeto pedagógico moderno. Como profundo conhecedor do homem, Nietzsche em seu tempo, já percebeu a impossibilidade de realização plena dos ideais iluministas e vai procurar tirar o véu de Maia (NIETZSCHE, 2003, p. 30) da realidade. Para ele, o sentido da vida, da história, os valores morais, não se estabelecem por um suprassensível, por um a priori, mas, estabelecem-se como perspectivas humanas. Tanto o conhecimento quanto a moral são tentativas do homem em impor ordem ao mundo. A força da qual deriva tanto a capacidade de conhecer quanto a capacidade de produzir valores é a vontade de poder.

Para Safranski (2001, p.294), Nietzsche pensa a vida como potência criadora e nesse sentido a chamara de vontade de poder. A vontade de poder é o impulso básico, está em obra em todo vivente, não se restringe à autoconservação, é uma busca em tornar-se mais. Os seres vivos não procuram apenas se manterem vivos, querem dar vazão à sua força. "Os fisiólogos deveriam refletir antes de estabelecer o impulso de 
autoconservação como o impulso cardinal de um ser orgânico uma criatura viva quer antes de tudo dar vazão a sua força - a própria vida é vontade de poder-: a autoconservação é apenas uma das indiretas, mais frequentes consequências disso". (NIETZSCHE, 2005, p.19). O "conceito chave" vontade de poder está na origem inclusive da nossa atividade racional: "O mundo visto de dentro, o mundo definido e designado conforme o seu caráter inteligível - seja justamente vontade de poder e nada mais." (NIETZSCHE, 2005, p. 40). Para Nietzsche "A razão não é mais do que poder, do que vontade de poder pervertida que esconde tão esplendidamente". (HABERMAS, 2002c, p. 81).

Safranski (2001, p. 264) afirma que Nietzsche enxergou que o poder não é algo substancial, mas relacional, e, a vontade de poder é a multiplicidade das forças em combate umas com as outras. É o jogo e o contrajogo dessa multiplicidade de forças. As unidades de poder são mutáveis, a unidade é apenas organização, sob a ascendência transitória de vontades de poder dominantes. Dessa forma: "A unidade de formação de domínio, nas quais está inserida a multiplicidade de quanta de força, não tem nenhum ser." (MÜLLER-LAUTER, 1997, p. 75). O ser é uma ficção vazia. A unidade é uma tentativa de nosso intelecto para compreender e simplificar a realidade, o que leva ao engano e à ilusão. "De fato, nada até agora teve mais ingênua força persuasiva do que o erro do ser,..." (NIETZSCHE, 1996, p. 375). Por isso, na tentativa de autoafirmação, de criar, de querer mais, a vontade de poder cria um número infinito de "verdades". Dessa forma, para Nietzsche, conhecer é um processo de poder no qual estão em jogo forças criativas, e que produz figuras e ideias acabadas, que se afirmam como verdade na medida em que possuem poder para tal, na medida em que se impõe como tal. Se as verdades não são dadas a nós a priori e sim criadas por nós, elas são, portanto, interpretações que fazemos da realidade, são perspectivas em meio a inúmeras outras. O critério de verdade deixa de ser universal e passa a ser condicionado ao poder que a interpretação possui para se estabelecer. 
Todas as interpretações são perspectivas; não há qualquer parâmetro de medida no qual se pudesse provar qual é mais correta e qual a menos correta, o único critério para a verdade de uma exposição da efetividade consiste em que medida ela está em condições de se impor contra outras exposições. Cada exposição tem tanto direito quanto tem poder. A compreensão da perspectiva de todas as interpretações, a que conduz a doutrina da vontade de poder de Nietzsche, pode por isso, propiciar aos que são fortes em poder a boa consciência para a incondicional imposição de seus ideais. (MÜLLER-LAUTER, 1997, p. 131).

Segundo Zatti (2008, p. 105), Nietzsche refuta a existência de conhecimentos profundos no sentido metafísico, para ele o conhecimento é uma força de superfície. Para o filósofo alemão, o conhecer se faz por meio de conceitos e assim sendo, o pensar é um denominar, o que decorre do arbítrio do homem e não provém de nenhuma essência. Afirma que os conceitos correspondem à imagem, portanto, superficiais. Não havendo essência, o conhecimento permanece na superfície. "O que é verdade, portanto? Um batalhão móvel de metáforas, metonímias, antropomorfismos [...], após longo uso, aparecem a um povo sólidas, canônicas e obrigatórias: as verdades são ilusões [...]"(NIETZSCHE,1996, p. 57). Verdades são ficcionais, são ficções úteis a serviço da autoconservação, mas não apenas, servem para a afirmação da vontade de poder. Dessa forma Nietzsche põe em suspeita o poder esclarecedor da razão.

Não havendo um sujeito transcendental, não havendo um mundo em si, não havendo um absoluto que garanta a universalidade; só o sujeito pode constituir-se e constituir o mundo como forma de autoconservação e expressão de sua vontade de poder. Nietzsche mostra que o sujeito identifica-se com utilitarismo e subordinação, da mesma forma que a verdade, o sujeito possui caráter ficcional e se estabelece com função de autoconservação sob a forma de dominação e de disfarce. "O sujeito - tanto o sujeito da razão como o sujeito moral - é o grande invento no qual o próprio sujeito assume a dupla tarefa de vigiar e ser vigiado, de dominar e de ser dominado, de julgar e de ser julgado, de castigar e de ser castigado, de mandar e de obedecer." (LARROSA, 2005, p. 113). 
Nietzsche exclui a validade incondicional de qualquer construção que impõe o conhecer e o agir como fundamento absoluto. Para ele o único fundamento é o ato de fundar, impor, valorar, ato criativo que aprecia ou deprecia. Esse ato criativo é uma forma de interpretação que impõe sua perspectiva, também no campo moral. "A interpretação instituidora de novos valores, por parte dos futuros poderosos só pode ser, do mesmo modo, perspectivas" (MÜLLER-LAUTER, 1997, p. 132). Na Genealogia da Moral, Nietzsche (1998) procura mostrar que os conceitos de bom e mau não são conceitos que se estabelecem de acordo com uma razão prática universal. Esses conceitos são expressões do modo de ser daqueles que avaliam. Quem avalia estabelece um valor, que, portanto, não é fato moral e sim uma interpretação moral. Para Nietzsche (1998, p. 33-34), a instituição da moralidade teve papel central na formação do que chamamos de civilização. O homem foi tornado confiável, sociável, por meio do que Nietzsche chamou de moralidade do costume, que teve papel fundamental para inscrever no homem o social, contendo-lhe os instintos. A moralidade do costume transformou o homem em animal manso, civilizado, doméstico. Foi a partir do momento em que o homem foi capaz de fazer promessas que foi possível um homem constante, uniforme, confiável. Mas, como o homem tem tendência natural para esquecer, e também o que causa dor fica por mais tempo na memória, os povos utilizaram castigos, sacrifícios, martírios para que as promessas não fossem esquecidas. Isso foi feito em especial pelas religiões. Com a ajuda dessa espécie de memória, chegou-se à razão, que proporciona seriedade, domínio sobre os impulsos.

Segundo Mühl (2005, p. 123), para Nietzsche, a compulsão por considerar como verdadeiros os pré-juízos a priori da razão não resulta do fato desses serem verdadeiros no sentido transcendental, mas seu sentido de verdade emerge da necessidade que temos em considerá-los de tal forma em função da exigência de nossa sobrevivência. A constituição da razão humana, da sua lógica, das suas categorias a priori, de princípios práticos a priori, decorre da necessidade de 
sobrevivência da espécie, mas com o tempo sua origem é esquecida e toma status de verdade com pretensão de validade metafísica. Dessa forma o processo civilizatório se desenvolve muito mais por meio de um interesse técnico de autoconservação do que por um interesse emancipatório.

Nietzsche é o ponto de viragem que deu início à crítica ao poder unificador, fundamentador e emancipatório da razão. Segundo Habermas (2002, p. 141), Heidegger retoma os motivos essenciais do messianismo dionisíaco de Nietzsche, escapando porém das aporias de uma crítica auto-referencial da razão. Heidegger pressente um resto não extinto do pensamento iluminista na estratégia de desmascaramento da teoria do poder de Nietzsche. Heidegger quer atingir a meta de Nietzsche, mas para tal, busca a destruição da metafísica ocidental de modo imanente. Para Heidegger a concepção de ser presente na metafísica ocidental originou uma concepção de mundo que conduz à dominação e à exploração. Esses males da racionalidade científica e técnica, a racionalidade instrumental, não decorrem de um desvirtuamento ou de uma patologia que se manifesta nas sociedades modernas, mas são resultado da perda do sentido do ser, o que remonta ao início da racionalidade ocidental. De acordo com Habermas (2002, p. 189), Heidegger vê na essência totalitária de sua época, caracterizada pelas técnicas de dominação da natureza de abrangência global, de estratégia bélica e de criação de raças, a absolutização da racionalidade com respeito a fins, própria do 'cálculo meticuloso de toda ação e planejamento'. Essa racionalidade funda-se na compreensão especificamente moderna do Ser: o homem tornou-se meio e medida do ente. A dominação moderna do sujeito está inserida na história da metafísica, e, a história da sociedade moderna é a história da metafísica nascida na Grécia com Platão que se caracteriza como história do esquecimento do ser, por isso Heidegger vai remontar às origens da metafísica. Ele analisa a metafísica como o pensamento que se ocupa com o ente e se esquece do problema do ser. 
Dessa forma, Heidegger (2005), em Ser e Tempo, busca a problematização da pergunta feita por Aristóteles no início da filosofia: o que é o ser? Para Heidegger, a pergunta é significativa, mas a resposta de Aristóteles é equivocada porque diz que o ser é algo, isso ou aquilo. O ser do ente consiste, dessa forma, na entidade. Ao dizer que o ser é algo que aparece, somos determinados por uma estrutura de racionalidade como modo de pensar, pois o ser é aquilo que é identificado pela razão. Isso encerra a questão porque estabelece uma resposta definitiva, determinista, ao entender o ser como aquilo que se desvela à nós. Por isso, Heidegger propõe dar um "passo atrás" e retomar a pergunta feita por Aristóteles para irmos além da chamada história oficial da filosofia ocidental.

A filosofia grega nasce com a atitude de admiração e espanto diante do fato de que o ente é no ser. Mas o saber filosófico grego não se deteve somente nesse espanto, moveu-se na direção da busca de uma compreensão do ser do ente, para além da percepção do ente no ser. "Isso foi feito basicamente por Platão e Aristóteles, que certamente sabiam muito bem que o ente é no ser, mas estabeleceram nesse campo um pensamento do ser do ente: a ideia em Platão e a enérgeia em Aristóteles." (WERLE, 2008, p. 24). Foi com essa ontologia que fundaram a metafísica que é base para o pensar ocidental e, concomitantemente, criaram dogmas fundantes para tal pensar.

\begin{abstract}
No solo da arrancada grega para interpretar o ser, formou-se um dogma que não apenas declara supérflua a questão sobre o sentido do ser como lhe sanciona a falta. Pois se diz: 'ser' é o conceito mais universal e o mais vazio. Como tal, resiste a toda tentativa de definição. Esse conceito mais universal e, por isso, indefinível prescinde de definição. Todo mundo emprega constantemente e também compreende o que ele, cada vez, pretende designar. Assim o que, encoberto, inquietava o filosofar antigo e se mantinha inquietante, transformou-se em evidência meridiana, a ponto de acusar quem ainda levantasse a questão de cometer um erro metodológico. (HEIDEGGER, 2005, p. 27-28).
\end{abstract}

Heidegger procura remontar o pensamento ao seu começo, à sua origem, e isso principalmente por ter havido um afastamento do homem de seu destino no 
mundo que, na linguagem heideggeriana, se traduz como sendo o esquecimento do ser na metafísica ocidental e redunda na confusão entre ser e ente. Para esclarecer essa questão, precisamos atentar à diferença ontológica entre ser, ente e dasein (presença). As coisas que estão a nossa volta são os entes. O ser é o fundamento escondido, é uma imersão que ao aparecer nos entes se esconde. O dasein é o ser que interpreta. O ser humano possui uma relação com o próprio ser, ao que Heidegger chama de existência. "Dasein ou existência significam, pois: nós não apenas somos, mas percebemos que somos. E nunca estamos acabados, [...], mas em todos os pontos estamos abertos para o futuro." (SAFRANSKI, 2000, p. 190). Heidegger (2005) define o homem como dasein (pre-sença), enquanto ente da linguagem, o único que faz a pergunta sobre o sentido do ser. Segundo Werle (2008, p. 26-27), com Heidegger a noção de razão e, por conseguinte, da filosofia, sofre uma profunda mudança de registro, pois trata-se de pensar o logos pela sua forma inicial de manifestação e de surgimento, o que remete para o tema da linguagem, como sendo justamente esse logos em estado nascente. A correspondência mais forte e original ocorre pela experiência da linguagem. É aqui a última instância que se realiza propriamente o sentido do logos. Exercer a razão é torná-la como processo de recolha, o que de fato ocorreu pela linguagem. A linguagem não consiste então numa mera operação específica de emitir palavras ou sons com significado, e sim, num ato de se pôr ou se inserir no ente em sua totalidade, de recolhê-lo deixando que seja.

Para Heidegger, o dasein (pre-sença) compreende seu ser, sendo. Ou seja, a pre-sença sempre compreende a si mesma a partir de sua existência. Em outras palavras, a característica ôntica do dasein consiste em que ele é ontologicamente. "A expressão ôntico designa tudo o que existe. A expressão ontológico designa o pensar curioso, espantado, assustado, sobre o fato de que eu existo e que qualquer coisa exista."( SAFRANSKI, 2000, p. 190). O homem é um ente que possui existência e, enquanto tal, não possui a essência previamente determinada, cabe a ele estabelecer os projetos para a própria existência. "Em Ser e Tempo Heidegger trabalha com a prova 
filosófica de que o Dasein humano não tem outro apoio senão esse aí (da), que é seu." (SAFRANSKI, 2000, p. 187). Isso remete à interpretação do tempo como o horizonte possível de qualquer compreensão do ser. O tempo é o horizonte aberto. Temporalidade é a experiência do passar presente, futuro e finalmente mortal. A temporalidade estabelece dois aspectos para o dasein: o ser para-a-morte e o serpossível. Dessa forma, o tempo é o sentido do ser, mas o tempo não nos dá sentido. Diante da pergunta pelo sentido há uma tendência em buscá-lo como algo no qual seja possível se orientar: Deus, moral, leis universais. Mas para Heidegger, isso representa uma fuga do dasein de sua temporalidade e de seu ser possível. Na tradição filosófica a pergunta pelo sentido foi feita e respondida como uma metafísica da presença, e aí caiu em absurdo engano. Para Heidegger o verdadeiro sujeito da pergunta pelo sentido do ser é a situação fundamental da angústia. É na angústia pela morte que o homem indaga pelo sentido de seu ser. Para Safranski (2000) a angústia é diferente do temor, ela é indeterminada e ilimitada. Temos angústia do mundo como tal. Diante da angústia tudo cai por terra, nu, despido de qualquer importância. "O que foi queimado pela angústia revelou o cerne de fogo do dasein: o ser-livre para a liberdade do escolher-a-si-mesmo e do apreender-a-si-mesmo." (SAFRANKI, 2000, 192).

A condição humana de ser-livre nos remete a um elemento central no pensamento de Heidegger, a historicidade. Sendo o homem um ente em especial (dasein), que escolhe-a-si-mesmo, o sentido só surge no homem e sua história. "Heidegger quer fazer seus ouvintes despencarem no grande vazio, escutarem o rumor fundamental da existência, quer abrir o momento em que nada mais interessa, em que não se oferece nenhum conteúdo de mundo em que a gente possa se agarrar ou com que possa se preencher."(SAFRANSKI, 2000, p. 236). Daí a crítica heideggeriana à objetificação. A vida humana nos escapa quando a queremos compreender de uma postura teórica, objetivadora. No pensamento objetivador desaparecem as relações de mundo e vida. Segundo Safranski (2000), para Heidegger, a objetificação científica do ser humano é um fugir da temporalidade inquietante do dasein. Para Stein (2002, p. 
129) a subjetividade elevada ao extremo faz de tudo o que ela encontra apenas material para a objetificação, dessa forma, a técnica se estabelece como 'deserto do ser', nela o ser está ausente. A técnica olha apenas nessa perspectiva, esquece que tudo é sustentado por algo mais profundo, que subjaz, se esconde e se vela. Por isso a técnica é o deserto do ser e o filosofar de Heidegger se volta para a "treva do mundo vivido". "A técnica é a perfeita objetivação da representação, portanto da tendência essencial da metafísica" (STEIN, 2002, p. 155).

Pela analítica existencial, em Ser e Tempo, Heidegger busca demonstrar que a racionalidade humana não se esgota no nível, lógico, epistemológico, metodológico. A modernidade ao estabelecer uma relação objetifivadora com as coisas, esquece do ser e busca na subjetividade individual o subterfúgio para implementar um processo de controle e manipulação. O desenvolvimento das ciências modernas é feito à custa do desaparecimento do pensamento dos fundamentos últimos do saber e do ser. Para Habermas (2002, p. 194), Heidegger volta-se sempre contra a abordagem monológica da filosofia da consciência.

O homem possui diante de si um horizonte temporal aberto e disponível no qual tem de viver. Para Heidegger o dispositivo fundamental para lidar com esse mundo é a preocupação (Sorge). "Heidegger usa a expressão no sentido de providenciar, planejar, importar-se, calcular, prever." (SAFRANSKI, 2000, p. 198). Como estamos jogados na existência, somos acontecimento do ser, vislumbramos um horizonte aberto, temos que nos importar com aquilo que nossa vida é e pode ser. 0 pensamento não tem nada a criticar e a combater, apenas deixar o ser acontecer, revelar-se. O homem não determina o sentido da existência e da história, quem determina é o ser. "O homem não é mais o guardador de lugar do nada, mas o guardião do Ser, o ser-mantido-para-fora na angústia cede à alegria e ao agradecimento pela benevolência do Ser, a teimosia do destino cede à submissão do destino do Ser, a autoafirmação ao devotamento" (HABERMAS, 2002, p. 214). O ser é o mistério que se revela ao homem de forma imprevisível, aleatória, contingente. 
O acontecer do Ser pode ser apenas experimentado com devoção e exposto em narrativas não podendo ser alcançado nem explicado com argumentos. Heidegger rejeita o conceito de liberdade da ontologia existencial. O ser-aí não é mais considerado como o autor dos projetos do mundo à luz dos quais o ente se mostra e se retira de uma só vez; ao contrário, a produtividade da criação de sentido que abre o mundo passa para o Ser mesmo. O ser-aí submete-se à autoridade do sentido incontrolável do Ser e despoja-se da vontade de auto-afirmação, suspeita de subjetividade. (HABERMAS 2002, p. 215).

Dessa forma, para Heidegger, a liberdade não diz respeito à vontade do ser humano, ela é inerente ao ser. Se não está ligada à vontade do ser humano, ela não pode ser entendida como autonomia e não possui poder emancipador. Liberdade representa antes o retorno ao estado autêntico do ser-para-a-morte. Para ele, não há liberdade no coletivo, este é sempre manifestação de perda da autenticidade. Dessa forma Heidegger nega o poder emancipador da humanidade na coletividade e pela crítica ao sujeito solipsista, apresenta um indivíduo que encontra sua autenticidade ao assumir sua condição de ser mortal e elimina a possibilidade do sujeito consciente, ativo, transformador, crítico capaz de emancipação.

Nietzsche e Heidegger são os filósofos que levantam suspeitas radicais a metafísica ocidental e seu otimismo de construção racional de sociedades esclarecidas. Nietzsche descontrói a noção de telos, ao inverter o platonismo põe fim à visão dualista de mundo (sensível/suprassensível) e estabelece o niilismo como horizonte de interpretação da metafísica. Heidegger descontrói a noção de arché, "nega o fundamentalismo do pensamento que se baseia em um primeiro, tanto faz se se apresenta nas formas tradicionais da metafísica ou nas da filosofia transcendental de Kant até Husserl." (HABERMAS, 2002, p. 215). Essa suspeição dos fundamentos metafísicos leva à meditação sobre a técnica, tendo em vista que a tendência essencial da metafísica é a objetivação da representação, o que é feito de forma mais perfeita pela técnica. 
Penso que podemos vislumbrar aqui, paradoxalmente, uma estranha cumplicidade entre Heidegger e Nietzsche, pelo menos quanto a certos aspectos de seu pensamento ligados à sua intransigente recusa da sociedade dos últimos homens. Em ambos os filósofos podemos discernir uma denúncia do delírio onipotente, configurado na vontade coletiva de poder que determina o modo de ser do mundo moderno: em Nietzsche ela assume mais a forma de uma reflexão sobre o aprofundamento e a extensão do niilismo, ao passo que em Heidegger se apresenta mais como uma meditação sobre a essência da técnica. Em comum entre ambas existe uma tentativa de alertar para os perigos inerentes à cega confiança nas virtualidades do fazer humano, potencializado pela ciência moderna. (GIACOIA JÚNIOR, 2005, p. 207).

Segundo Martini (2009, p. 25), para Vattimo a articulação da posição de Heidegger e Nietzsche aponta para a crise do humanismo pois ele se identificou com a metafísica ao estabelecer a técnica como projeto global da ciência moderna que reduz a compreensão de todos os entes à vínculos causais, previsíveis e domináveis. A técnica em sua aparência parece ameaçar a metafísica e o humanismo, mas, humanismo, metafísica e técnica têm a mesma origem, a "concepção de ser como fundamento que assegura a razão e na qual a razão se assegura"(idem).

\section{Escola De Frankfurt: a Dialética do Esclarecimento}

Adorno (2006, p. 181) na obra Educação e emancipação, afirma que Kant definiu a emancipação de uma forma inteiramente consequente, como uma categoria dinâmica, como um vir-a-ser e não um ser, ao afirmar que não vivia em uma época esclarecida e sim de esclarecimento. Mas Adorno alerta que se não quisermos usar a palavra emancipação em um sentido meramente retórico, é preciso ver efetivamente as enormes dificuldades que se opõe à emancipação em nossa organização do mundo. Adorno e Horkheimer na obra Dialética do esclarecimento partem do diagnóstico da racionalidade prevalecente e constatam um paradoxo que não apresenta um horizonte de superação: a racionalidade perdeu seu caráter emancipador, concebida como esclarecimento não consegue esclarecer-se a si mesma. 
Segundo Adorno e Horkheimer (2006, p. 17), “[...] o esclarecimento tem perseguido sempre o objetivo de livrar os homens do medo e de investi-los na posição de senhores", seu programa "[...] era o desencantamento do mundo. Sua meta era dissolver os mitos e substituir a imaginação pelo saber". Bacon compreendeu bem a mentalidade da ciência que se seguiu a ele ao perceber que o suposto casamento feliz entre entendimento humano e natureza se estabelece como uma relação "patriarcal", ou seja, o entendimento vence a superstição ao imperar sobre a natureza desencantada. Esse saber não visa conceitos, imagens ou o prazer do entendimento, mas o método, a utilização do trabalho, o capital, é portanto, técnico. "A técnica é a essência desse saber." (ADORNO; HORKHEIMER, 2006, p. 18). Para os iluministas, por meio da técnica e da ciência, os homens se tornariam senhores do mundo libertos do mito e da magia, no entanto, o homem tornou-se vítima do progresso da dominação técnica. Dessa forma, a razão vai perdendo seus vínculos com a proposta originária de uma pretensa emancipação, segundo Prestes (1996, p.28), a confiança na razão capaz de assegurar o progresso da humanidade é submetida a um desmoronamento pela não realização de metas previstas de libertação do homem e advento de formas de tirania e obscurantismo.

Por isso Adorno e Horkheimer elaboram uma crítica ao processo de instrumentalização da razão. Segundo Mühl (2003, p. 136), eles entendem que o sentido fundante da modernidade é o domínio sobre a natureza externa objetivada e a natureza interna reprimida, o que fez com que toda a racionalidade fosse submetida aos ditames da racionalidade instrumental, cuja expressão teórica suprema é a ciência moderna, que entendida positivamente, substitui toda aspiração de conhecimento do mundo por sua utilização técnica.

O saber que é poder não conhece barreira alguma, nem na escravização da criatura, nem na complacência em face dos senhores do mundo.[...] O que os homens querem aprender da natureza é como empregá-la para dominar completamente a ela e aos homens. Nada mais importa. Sem a menor consideração consigo mesmo, o esclarecimento eliminou com seu cautério o último resto de sua própria autoconsciência. Só o pensamento que se faz 
violência a si mesmo é suficientemente duro para destruir os mitos". (ADORNO; HORKHEIMER, 2006, p. 18).

Dessa forma os filósofos diagnosticam um paradoxo constitutivo no processo de esclarecimento, para o qual não há um horizonte de superação. A razão, na medida em que é concebida e gerada como esclarecimento, perde seu caráter emancipador por não ser capaz de esclarecer-se a si mesma. Desse modo, o motivo básico da frustração do projeto emancipador moderno reside no conceito de razão que orientou tal projeto, a razão instrumentalizada. Segundo Jaehn (2005, p. 53), ela constituiu-se como razão que pondera, calcula e ajusta os melhores meios a fins, portanto, acontece em sentido contrário ao projeto moderno de emancipação que exigia a determinação racional de fins. A racionalidade instrumental é um processo que absorve o sujeito, tolhe a reflexão sobre seu próprio pensamento e, produz assim, “[...] o pensamento coisificado e, por consequência, a coisificação do sujeito, que para os autores de Dialética do Esclarecimento, significa a subjetivação dos sujeitos em forma de 'coisas' ou 'objetos'."(JAEHN, 2005, p. 53). Esse processo tem início com a abstração da ciência moderna, o sujeito se distancia do objeto para conhecer e dominar a sua natureza, o que resulta num processo de intensa exploração que se estende para a natureza psíquica. Dessa forma, a ciência procede da mesma maneira com a natureza física e psíquica, oferecendo uma poderosa base de sustentação para a cultura moderna continuar com o processo de dominação e exploração. É a 'coisificação do sujeito', que em Luckács se expressa como 'reificação dos sujeitos'.

Adorno e Horkheimer iniciam a obra Dialética do esclarecimento falando sobre o conceito de esclarecimento, o que é fundamental para compreendermos a crítica que fazem à razão moderna. Para Kant o conceito de esclarecimento estava ligado a um processo de emancipação intelectual resultado da superação da menoridade auto-culpada, que levava o homem a pensar por conta própria, ou seja, de acordo com os ditames das próprias leis racionais. Segundo Almeida $(1985$, p. 7), em Adorno e Horkheimer o termo esclarecimento é usado para designar um processo de "desencantamento do mundo", pelo qual as pessoas se libertam do medo de uma 
natureza desconhecida, com poderes ocultos. Por isso o esclarecimento de que falam se diferencia do conceito dos filósofos iluministas: é o processo pelo qual ao longo da história os homens se libertam das forças míticas da natureza, "é o processo de racionalização que prossegue na filosofia e na ciência".

Assim compreendem o esclarecimento como um movimento que iniciou com a filosofia pré-socrática, tendo como característica o embate entre mito e razão e que culminou na modernidade com o embate entre razão e religião. (cf. JAEHN, 2005, p. 54). A ciência moderna ao tentar sobrepor a mitologização por meio da instrumentalização racional, se transforma em uma nova mitologia. Segundo Jaehn (2005, p. 54-55), para Adorno e Horkheimer, tanto o mito quanto a ciência trazem como característica central o desejo e necessidade de dominação da natureza e do próprio homem. Mas na magia a dominação era um processo explícito, significando a verdade das coisas e a base do mundo. Já no esclarecimento moderno, a dominação ocorre de maneira implícita. Por meio da abstração, que se caracteriza como fragmentação das partes e distanciamento do sujeito em relação ao objeto, se estabelece um processo de redução, mensuração, controle, dominação. A concepção de verdadeiro passa a estar ligada ao mensurável. "O que não se submete ao critério da calculabilidade e da utilidade torna-se suspeito para o esclarecimento". (ADORNO; HORKHEIMER, 2006, p. 19). Pautado na calculabilidade o esclarecimento busca construir um sistema através do qual possa deduzir todas as coisas. "O esclarecimento é totalitário". (Idem).

Para Adorno e Horkheimer (2006, p.20), nos últimos escritos de Platão exprime-se o anseio de desmitologização, tornando o número o cânon do esclarecimento. Para o esclarecimento tudo o que não se reduz aos números, à unidade, é ilusão. Essa busca por unidade exige a destruição dos deuses e mitos. "Mas os mitos que caem vítimas do esclarecimento já eram o produto do próprio esclarecimento. [...] O mito queria relatar, denominar, dizer a origem, mas também expor, fixar, explicar". (ADORNO; HORKHEIMER, 2006, p. 20). Os mitos, da forma como 
se encontram nos poetas trágicos, já estavam sob o signo da disciplina e do poder que Bacon enaltece como o objetivo a ser alcançado na modernidade. Com o desenvolvimento da filosofia o ser se resolve no logos e a distinção entre logos e realidade submete todas as outras distinções; o mundo é submetido ao domínio dos homens. "O despertar do sujeito tem por preço o reconhecimento do poder como o princípio de todas as relações." (ADORNO; HORKHEIMER, 2006, p. 21). A unidade da razão estabelece a separação entre Deus e homens, mas também impõe uma semelhança quanto à soberania, ao comando. Tanto na religião judaica quanto na religião olímpica o mundo aparece como submetido aos domínios do homem.

\begin{abstract}
O mito converte-se em esclarecimento, e a natureza em mera objetividade. O preço que os homens pagam pelo aumento de seu poder é a alienação daquilo sobre o que exercem o poder. $O$ esclarecimento comporta-se com as coisas como o ditador se comporta com os homens. Este conhece-os na medida em que pode manipulá-los. O homem da ciência conhece as coisas na medida em que pode fazê-las. É assim que seu em-si torna para-ele. Nessa metamorfose, a essência das coisas revela-se como sempre mesma, como substrato da dominação. Essa identidade constitui a unidade da natureza. Assim como a unidade do sujeito, ela tampouco constitui um pressuposto da conjuração mágica. (ADORNO; HORKHEIMER, 2006, p. 21).
\end{abstract}

$\mathrm{Na}$ magia os rituais se dirigiam aos fenômenos da natureza como seres espirituais, exemplo são os ritos através dos quais o xamã se dirigia ao vento, à chuva, à serpente, e não à matérias ou exemplares da natureza. A ciência através da classificação e abstração desqualifica a natureza para abstração. A partir da abstração e da consequente dominação sobre os objetos, a ciência consegue transformar em coisa não apenas os objetos mas o próprio homem. Segundo Habermas (2002, p. 157), Adorno e Horkheimer buscam demonstrar que os homens formam sua identidade na medida em que aprendem a dominar a natureza exterior ao preço da repressão da natureza interior. Tanto a ciência quanto a magia buscam alternativas para aproximarse da natureza e compreendê-la. Ambas visam fins, mas a magia os persegue pela mimese, já a ciência pelo distanciamento progressivo em relação ao objeto. Para Adorno e Horkheimer (2006, p. 22-23), para substituir as práticas do curandeiro pela 
técnica industrial universal foi preciso, primeiro, que os pensamentos se tornassem autônomos em face dos objetos.

Segundo Jaehn (2005, p. 57), a pretensão de explicar tudo através de um processo repetitivo de fragmentação da natureza, tendo por objetivo conhecê-la para dominá-la e livrar o homem do medo e da insegurança do desconhecido, é para a ciência moderna uma defesa e superação da mitologia. Para Adorno e Horkheimer isso representa um retorno à mitologia, a ciência se transforma em um novo mito. Por isso desenvolvem a tese de que mito e ciência se comportam da mesma forma diante do objeto. "A abstração, que é o instrumento do esclarecimento, comporta-se com seus objetos do mesmo modo que o destino, cujo conceito é por ele eliminado, ou seja, ela se comporta como um processo de liquidação". (ADORNO; HORKHEIMER, 2006, p. 24). De forma contraditória, a continuidade da tentativa de superação do mito e de dominação é sustentada pela tese da autopreservação. Segundo Maar (2004, p. 171) as pessoas aceitam as determinações objetivas porque esta aceitação é uma espécie de "passaporte" para viverem na sociedade vigente. Dessa forma as pessoas produzem a barbárie no próprio processo de reprodução material da vida em sociedade, produzem a barbárie que as aprisiona, ou, produzem o produto a se que se sujeitam. Mas o distanciamento entre sujeito e objeto, a consequente lógica discursiva que postula a universalidade do pensamento, se estabelecem fundadas na dominação do real, na distância em relação à coisa que o senhor conquista através do dominado.

\footnotetext{
A universalidade dos pensamentos, como a desenvolve a lógica discursiva, a dominação na esfera do conceito, eleva-se fundamentada na dominação do real. É a substituição da herança mágica, isto é, das antigas representações difusas, pela unidade conceptual que exprime a nova forma de vida, organizada com base no comando e determinada pelos homens livres. $\mathrm{O}$ eu, que aprendeu a ordem e a subordinação com a sujeição do mundo, não demorou a identificar a verdade em geral com o pensamento ordenador, e essa verdade não pode substituir sem as rígidas diferenciações daquele pensamento ordenador. Juntamente com a magia mimética, ele tornou tabu o conhecimento que atinge efetivamente o objeto. (ADORNO; HORKHEIMER, 2006, p. 25).
} 
Dessa forma Adorno e Horkheimer visualizam uma cumplicidade entre mito e esclarecimento. Habermas (2002, p. 158) referindo-se à ideias de Adorno e Horkheimer, afirma que no processo histórico-universal do esclarecimento, a espécie humana distanciou-se cada vez mais de suas origens, mas não se livrou da compulsão mítica de repetição. 0 mundo moderno como mundo racionalizado, é desencantado apenas na aparência. "Nos fenômenos de paralisia de uma emancipação a correr no vazio, manifesta-se a vingança dos poderes originários contra aqueles que precisavam emancipar e, todavia, não conseguiam escapar". (Idem). A pressão para dominar racionalmente as forças naturais colocou os sujeitos num processo de formação que intensifica as forças produtivas em prol da autoconservação. Assim a dominação de uma natureza exterior objetivada e uma natureza interior reprimida são constituidores do esclarecimento. Segundo Mühl (2003, p. 145-146), para Adorno e Horkheimer a história mundial não é o progresso na consciência da liberdade, mas a totalização progressiva da dominação. O esclarecimento se faz por meio de uma contradição irremediável entre progresso e liberdade, a vitória sobre a natureza externa, por meio do desencantamento do mundo e desenvolvimento das forças produtivas, traz o preço da repressão crescente da natureza interna. Portanto a história da racionalidade ocidental se configura pela dominação e abnegação. Assim a dominação e a reificação são fenômenos derivados da própria razão.

Adorno e Horkheimer compreendem o esclarecimento como a relação racional do homem com o mundo, que é um processo de dominação do homem sobre a natureza, processo de unificação da cultura ao redor de elementos abstratos do conhecimento. A cultura para nos dar liberdade em relação à natureza cobra a subjugação do homem ao aparato técnico que nos permite subjugar a natureza, assim, a dominação que os homens estabelecem em relação à natureza é repetida no interior da sociedade. O esclarecimento caminha na direção da unificação da cultura que se faz por meio da falsificação da vida humana e cobra o esquecimento dos aspectos individuais que são contrários à unificação. Portanto, não são apenas os regimes 
totalitários que são unificadores, eles são um exemplo extremo daquilo que toda cultura buscou, a unificação total dos indivíduos. A racionalidade é o que possibilitou ao longo da história aos seres humanos constituir a cultura que tende a unificação. Adorno e Horkheimer buscaram questionar esse movimento de unificação. Demonstraram que o pensamento mítico antigo já se configurava como um processo de racionalização, ou seja, ao mesmo tempo uso de uma capacidade humana para dominar a natureza e unificação dos seres humanos para degladiar com ela de forma mais eficiente. 0 mito já é um processo de racionalização que opera por meio da repetição, remonta às origens e busca por meio da repetição atualizar um elemento fundamental. Adorno afirma que a ciência possui elementos mitológicos, estabelece verdades, formulações genéricas, explicações substanciais, que se repetem independente das particularidades, dessa forma valem para todas as coisas. Isso é mais do que uma analogia entre mito e razão, ambos repetem elementos que são postos como fundamento e possibilitam a unificação, assim, ambos fazem parte do mesmo processo de dominação da natureza. Os filósofos frankfurtianos afirmam que o conhecimento nunca foi cultivado por meio de um desejo de verdade, sempre houve um desejo técnico, operatório, a origem da ciência está ligada ao desejo humano de dominar a natureza. O processo de unificação da cultura é repetido internamente e estabelece a dominação da natureza interna, isso faz com que o homem ganhe identidade. A subjugação faz com que a sociedade produza uma identidade de progresso material em detrimento das diferenças individuais qualitativas, as pessoas tornam-se eficazmente iguais. Há a submissão aos processos de produção para que se renda mais, e isso anula as diferenças entre as pessoas. Essa padronização ocorre inclusive na indústria cultural.

Para Adorno e Horkheimer o motivo básico da frustração do projeto emancipador nascido na modernidade com o iluminismo, foi o próprio conceito de razão que o orientou, a racionalidade instrumentalizada. "A razão instrumental é reducionista, unidimensional, levando o sujeito a desenvolver um tipo de 
procedimento em que o mundo exterior é reduzido a um objeto que pode ser manipulado de acordo com seu interesse". (MÜHL, 2003, p. 140). De acordo com Habermas (2002, p. 170), com o conceito de razão instrumental Horkheimer e Adorno querem acertar as contas com um entendimento calculador que usurpou o lugar da razão. Demonstram que a racionalidade instrumental, com respeito a fins, entertigada em totalidade, estreita a diferença entre aquilo que pretende validade e aquilo que é útil para a autoconservação, demolindo assim a barreira entre validade e poder, anulando aquela diferenciação conceitual básica que a apreensão moderna do mundo acreditava dever a uma superação definitiva do mito. Dessa forma a razão, enquanto razão instrumental, assimilou-se ao poder e renunciou à sua força crítica. Horkheimer e Adorno, com sua crítica total à razão, descrevem a autodestruição da capacidade crítica de modo paradoxal, visto que no instante da descrição ainda tem de fazer uso da crítica que declararam estar morta. Denunciam o esclarecimento que se tornou totalitário com os meios do próprio esclarecimento. Segundo Habermas (Idem), Adorno estava perfeitamente consciente dessa contradição performativa da crítica totalizada.

\footnotetext{
Horkheimer e Adorno encontram-se no mesmo embaraço que Nietzsche: se não renunciam ao efeito de um último desvelamento e querem prosseguir a crítica, precisam conservar intacto pelo menos um critério de todos os critérios racionais em sua explicação da corrupção. Em vista desse paradoxo, a crítica que atropela a si mesma perde a direção. (HABERMAS, 2002, p. 181).
}

Da mesma forma que Nietzsche, Adorno e Horkheimer promovem uma crítica total à razão e pela tese da dialética do esclarecimento, desembocam em um "beco sem saída", que no entender de Habermas é uma saída irracional.

O legado de Nietzsche, de desconstrução do projeto de esclarecimento, teve influência sobre os frankfurtianos e estendeu-se até a pós-modernidade, em pensadores como Foucault, Derrida, Lyotard, Vattimo. Todos eles desenvolvem suas críticas, fundados especialmente em Nietzsche e Heidegger, à concepção de razão e 
sujeito moderno com suas pretensões de unidade e universalidade. Portanto dão continuidade à corrente iniciada por Nietzsche que põe em suspeita o projeto emancipatório moderno.

\section{Habermas: Revisão da Teoria Crítica}

Em 1967 Habermas publica um ensaio com o título Trabalho e Interação. Notas sobre a filosofia do espírito de Hegel em Jena. O confronto de Habermas com a filosofia hegeliana vai ocasionar também a revisão do pensamento de Kant e Marx. Segundo Habermas (2009, p. 12), no escrito de juventude chamado Filosofia do espírito de Jena, Hegel desenvolve a ideia de três formas de mediação entre sujeito e objeto, a linguagem, o trabalho e a relação ética, expressos em três modelos básicos de relações dialéticas: linguagem, instrumento e família.

Diferentemente de Kant, Hegel nessa obra, "não conecta a constituição do Eu com a reflexão do Eu solitário sobre si mesmo"(HABERMAS, 2009, p. 23), mas a concebe a partir de processos de formação, a unificação comunicativa de sujeitos opostos.

\footnotetext{
A experiência da autoconsciência já não figura como originária. Para Hegel, resulta antes da experiência da interação, em que Eu aprendo a ver-me com os olhos do outro sujeito. A consciência de mim mesmo deriva de um entrelaçamento das perspectivas. Só com base no reconhecimento recíproco se forma a autoconsciência, que se deve fixar no reflexo de mim mesmo na consciência de um outro sujeito.(HABERMAS, 2009, p. 15).
}

Para Hegel o Eu só pode conceber-se como autoconsciência se for espírito, isto é, passar da subjetividade para a objetividade de um universal no qual, com base na reciprocidade, os sujeitos se unificam como não idênticos. Justamente porque o Eu é identidade do universal e do particular, a individuação de um recém-nascido só pode conceber-se como um processo de socialização. Socialização aqui não se entende a 
inserção de um indivíduo na sociedade, mas sim é a socialização que suscita o ser do indivíduo. (cf. HABERMAS, 2009, p. 17).

De acordo com Pinzani (2009, p. 57), o conceito hegeliano de espírito é interpretado por Habermas como um meio em que os indivíduos se comunicam e se formam como sujeitos em geral por meio do reconhecimento recíproco, o espírito é, desse modo, comunicação. Hegel explica essa forma de interação usando o exemplo do amor, que concebe como um reconhecer-se no outro. Segundo Habermas (2009, p. 17-18), na segunda série de lições de Jena, Hegel elucida o amor como o conhecer que no outro se conhece, apresenta o amor como reconciliação de um conflito prévio. 0 sentido de uma identidade, o Eu, baseada no reconhecimento recíproco, se revela sob o ponto de vista de que a relação dialógica da união complementar de sujeitos opostos representa simultaneamente uma relação da lógica e da práxis vital. Conforme Pinzani (2009, P. 57) Habermas retoma a crítica hegeliana de Kant e a amplia. Em Kant, as leis morais são pensadas como leis abstratas e gerais, que valem para todos seres racionais, o que faz com que a interação se dissolva em ações de sujeitos solitários que agem como se fossem a única consciência existente. $\mathrm{O}$ agir ético se reduz à ação monológica.

\begin{abstract}
A intersubjetividade da validez das leis morais, admitida a priori mediante a razão prática, permite a redução do agir ético à ação monológica. A relação positiva da vontade com as vontades dos outros é subtraída à comunicação possível e substituída pela concordância transcendentalmente necessária de atividades teleológicas isoladas, que obedecem a leis universais abstratas. Sendo assim, a ação moral, no sentido de Kant, apresenta-se mutantis mutandis como um caso especial do que hoje chamamos ação estratégica. (HABERMAS, 2009, p. 22).
\end{abstract}

Mas além do amor (família), há duas categorias que Hegel desenvolve como meios do processo de formação: linguagem e trabalho. A linguagem não abrange só a comunicação entre os sujeitos, mas também a atividade pela qual o indivíduo dá nome às coisas. Para Hegel, com a linguagem a consciência consegue separar o ser da consciência e o ser da natureza, ou seja, desenvolve uma experiência de si como 
sujeito separado dos objetos. A linguagem, desse modo, é a primeira categoria sob a qual o espírito é pensado não como algo interior, mas como um meio. O espírito é aqui logos de um mundo, e não da reflexão da autoconsciência solitária. (cf. HABERMAS, 2009, p. 25). O trabalho é uma forma específica de satisfação das necessidades que distingue o espírito da natureza. Enquanto a linguagem ordena o caos das múltiplas sensações em coisas identificáveis, o trabalho suspende o processo de satisfação das necessidades. "E assim como o meio era, além, constituído pelos símbolos lingüísticos, aqui, é o mesmo constituído pelos instrumentos [...]"(HABERMAS, 2009, p. 25). Enquanto os símbolos permitem o reconhecimento do mesmo, os instrumentos fixam as regras segundo as quais pode se repetir a sujeição dos processos naturais, assim a subjetividade do trabalho é no instrumento elevada a algo universal, todos podem imitá-lo e trabalhar da mesma forma. A dialética do trabalho estabelece uma relação sujeito-objeto. Inicialmente há a sujeição do sujeito ao poder da natureza externa, mas, na experiência do trabalho o homem elabora o instrumento e através dele faz a natureza trabalhar em seu favor, ficando livre de seu poder. Assim, pela astúcia, mediante os instrumentos, a sujeição do sujeito pela natureza segue-se à sujeição da natureza pelo sujeito.

Os três tipos de relação dialética entre sujeito e objeto desenvolvidas nas Lições de Jena, realçam os processos de formação da identidade constituída da consciência que dá nomes, da consciência astuta e da consciência reconhecida, contrapondo a concepção de Eu de Kant. Mas à crítica da moralidade corresponde uma crítica da cultura. Kant considera a cultura como o fim último da natureza, o que significa, objetivamente, a cultura como a totalidade do domínio técnico sobre a natureza. O eu cultivado a que Kant atribui a idoneidade para a ação instrumental é, pelo contrário, concebido por Hegel como um resultado de um processo de trabalho que se modifica com o movimento da história. (cf. HABERMAS, 2009, p. 27). Analogamente, ao demonstrado por Hegel quanto à consciência moral e técnica, a dialética da representação mediante símbolos lingüísticos dirige-se contra o conceito 
kantiano de uma consciência transcendental em geral abstraída de processos de formação. A identidade do Eu não pode pressupor-se aos processos de conhecimento e também não aos processos de trabalho e interação, dos quais provém a consciência astuta e reconhecida. A identidade da consciência cognoscente só se constitui com a linguagem na qual é possível a síntese dos momentos separados do Eu e da natureza como mundo do Eu. Enquanto Kant parte da identidade do Eu como uma unidade originária da consciência transcendental, Hegel é levado à experiência fundamental do Eu enquanto identidade do universal e do particular. Hegel desenvolve a tríplice identidade da consciência que dá nomes, da consciência astuta e da consciência reconhecida, que contrapõe a unidade abstrata da vontade prática, da vontade técnica e da inteligência, como pensara Kant.

Mas como pensar a unidade do processo formativo que segundo as Lições de Jena ocorre através da dialética da linguagem, do trabalho e da interação? Segundo Habermas (2009, p.30-31), Hegel introduz a utilização de símbolos representativos como a primeira determinação do espírito abstrato, as duas determinações seguintes pressupõem esta. Na dimensão do espírito real, a linguagem adquire existência como sistema de uma determinada tradição cultural. Como tradição cultural, a linguagem entra na ação comunicativa, pois só as significações intersubjetivas válidas e constantes, que se obtêm da tradição, facultam orientações com reciprocidade, assim, a interação depende das comunicações linguísticas que se tornam familiares. Também a ação instrumental, logo que aparece como trabalho social, está inserida numa rede de interações e depende das condições comunicativas e da cooperação. Mas a ação instrumental pode ser uma ação monológica na medida em que abstraída do trabalho social e se considerarmos o ato solitário do uso do instrumento. "Certamente as regras técnicas só se formam sob as condições da comunicação linguística, mas nada têm em comum com as regras comunicativas de interação". (HABERMAS, 2009, p. 31). Hegel constrói a conexão entre ação instrumental e a interação no produto reconhecido do trabalho, no sistema do trabalho social. A relação do recíproco reconhecimento em 
que se funda a interação é regulamentada por meio da reciprocidade implicada na troca dos produtos do trabalho. As normas jurídicas que se estabelecem nas sociedades é que consolidam a ação com base no reconhecimento recíproco e, consequentemente, consolidam o resultado de uma libertação da natureza mediante o trabalho social.

Marx, sem conhecer os manuscritos de Jena, redescobre na dialética de forças produtivas e relações de produção, a conexão entre trabalho e interação, no entanto, a aplica ao processo de formação da espécie e não do espírito. Marx “[...] tentou reconstruir o processo histórico-mundial de formação do gênero humano a partir das leis de produção da vida social". (HABERMAS, 2009, p. 41). Mas Marx não explica efetivamente a conexão entre trabalho e interação, sob o título de práxis social, reduz um ao outro, ou seja, ação comunicativa à ação instrumental. Na atividade produtiva o uso dos instrumentos estabelece uma mediação entre sujeito que trabalha e os objetos naturais, essa ação instrumental se transforma em paradigma para obtenção de todas as categorias. Habermas critica Marx por ele não ter percebido que ao lado do trabalho há uma outra dimensão igualmente decisiva para a reprodução social, a interação e portanto, a comunicação. Nesse contexto, Habermas utiliza-se do par conceitual agir instrumental e agir comunicativo. A teoria social de Habermas leva em conta não somente os aspectos da reprodução material por meio do trabalho, mas também a dimensão comunicativa pela qual é efetuada a integração social por meio de normas. Desse modo, a história do gênero humano constitui um processo em que ambas dimensões estão conectadas. Segundo Pinzani (2009, p. 36), Habermas compartilha com Heidegger a desconfiança contra a técnica moderna que conquistou sub-repticiamente todos os âmbitos de nossa cultura. Por isso, ele acusa Marx de não ter prestado atenção ao papel da técnica na sua teoria da alienação, o que aliena o trabalhador da sua atividade e do produto do seu trabalho é, não tanto a forma capitalista de produção, como pensava Marx, mas a técnica. 
Habermas (2009, p. 42) afirma que o desencadeamento das forças produtivas técnicas, que inclusive são capazes de exercer controle e superam a capacidade humana no que se refere a atividade instrumental, não se identifica com a formação de normas que possam consumar a relação ética numa interação isenta de dominação, com base numa reciprocidade que se desenvolve sem coações. "A emancipação relativamente à fome e à miséria não converge necessariamente com a libertação a respeito da servidão e da humilhação, pois não existe uma conexão evolutiva automática entre trabalho e interação". (Idem). Segundo MacCarthy (1995, p.42), não devemos identificar emancipação política e progresso técnico, enquanto a racionalização na dimensão instrumental significa o crescimento das forças produtivas e a ampliação do controle tecnológico, a racionalização na dimensão da interação social significa a extensão de uma comunicação livre de domínio. Portanto, o desenvolvimento das forças produtivas, a emancipação do homem em relação à coação da natureza, não significa de forma imediata a substituição das relações de dominação por relações comunicativas, não significa que a sociedade esteja emancipada da força social. Desse modo, para Habermas (2009, p.43) nem a Filosofia do espírito de Jena nem a Ideologia alemã esclarecem de forma satisfatória a relação entre trabalho e interação da qual depende essencialmente o processo de formação do espírito e da espécie.

Mas de acordo com MacCarthy (1995, p. 55) mesmo assim essas interpretações de Marx e Hegel são instrutivas para a compreensão do próprio Habermas. Com trabalho Habermas pretende tematizar o processo pelo qual o homem se emancipa da natureza, com interação tematiza as relações sociais entre indivíduos capazes de comunicação. A insistência de Habermas na irredutibilidade e heterogeneidade entre trabalho e interação é justamente para evitar a fusão de técnica e práxis, de progresso técnico com comportamento racional na vida prática. Tal fusão está na raiz da ideologia tecnocrática. 


\section{Considerações Finais}

O projeto emancipatório moderno possui suas raízes em Descartes e Bacon, que fundam uma concepção de razão toda poderosa, e desse modo, estabelecem um otimismo científico triunfalista, segundo o qual, pela razão a ciência e técnica podem garantir o domínio sobre as forças da natureza e realizar a justiça nas relações entre os homens. Tal projeto científico e social otimista é levado ao seu ápice, de modo distinto, por Immanuel Kant e Karl Marx.

Kant, na Crítica da razão pura, resolve a disputa entre empirismo e racionalismo ao formular o seu juízo sintético a priori, o que possibilita ao conhecimento científico, ao mesmo tempo, ter a experiência como condição e fundar sua universalidade no sujeito racional. Todo projeto emancipatório kantiano possui como ancoradouro o sujeito transcendental e sua razão com status metafísico, que, desse modo, consegue estabelecer a verdade, o bom e o belo. Já Karl Marx funda seu projeto de emancipação em sua doutrina do materialismo histórico, que estabelece a categoria de trabalho como central para compreender o processo de desenvolvimento científico e social. Nietzsche, Heidegger e Adorno/Horkhkeimer desconstroem o projeto emancipatório moderno demonstrando seus fundamentos históricos e humanos. Os fundamentos pretendidos metafísicos de tal proposta são demonstrados como produto de uma história de interpretação humana.

Habermas na obra Trabalho e Interação. Notas sobre a filosofia do espírito de Hegel em Jena, conhecendo a desconstrução do projeto emancipatório moderno realizada pelos filósofos acima citados, busca reinterpretar as obras de Kant e Marx a partir da obra Filosofia do espírito de Jena de Hegel. O confronto de Habermas com a filosofia hegeliana vai ocasionar também a revisão do pensamento de Kant e Marx; tal reinterpretação vai possibilitar a reconstrução do projeto científico e social moderno a partir de novas bases, pós-metafísicas. Nessa obra, Habermas desenvolve os conceitos trabalho e interação, que são a chave para sua reconstrução do projeto emancipatório moderno. A distinção entre trabalho e interação abre a possibilidade para a posterior 
formulação dos conceitos de ação comunicativa e ação instrumental/ estratégica, razão comunicativa e razão instrumental, que serão desenvolvidos posteriormente para a formulação da teoria da ação comunicativa. Ainda, a distinção entre trabalho e interação possibilita a posterior elaboração dos conceitos de sistema e mundo da vida. O trabalho é compreendido como esfera típica do sistema onde opera a racionalidade instrumental, enquanto a interação é compreendida como típica do mundo da vida onde opera de modo legítimo a razão comunicativa. O sistema é o espaço para o desenvolvimento da técnica e da ciência e deve assegurar a reprodução material da sociedade, já o mundo da vida é o espaço intersubjetivo de interação responsável pela reprodução simbólica da sociedade. Tal reconstrução habermaseana resgata o ideário emancipatório da modernidade sob bases pós-metafísicas e elimina a possibilidade de elevação da técnica e ciência como a única instância de saber válido.

\section{Referências}

ABBAGNANO, Nicola. Dicionário de filosofia. 2ª Ed. São Paulo: Mestre Jou, 1962. ADORNO, Theodor. Educação e emancipação. 4a ed. Rio de Janeiro: Paz e Terra, 2006. ADORNO, Theodor; HORKHEIMER, Max. Dialética do esclarecimento. Rio de Janeiro: Jorge Zahar Ed, 2006.

ALMEIDA, Guido Antonio de. Nota preeliminar do tradutor. In: ADORNO, Theodor; HORKHEIMER, Max. Dialética do esclarecimento. Rio de Janeiro: Jorge Zahar Ed, 1985. p. 7-8.

CANIELLES, Ariela dos Santos; OLIVEIRA, Avelino da Rosa. A emancipação humana: uma abordagem a partir de Karl Marx. Anais [Recurso eletrônico]. V Encontro Brasileiro de Educação e Marxismo. Florianópolis: UFC/PPGE, 2011.

FLICKINGER, Hans Georg. Trabalho e emancipação: observações a partir da teoria marxiana.In: Veritas. v. 37, no 148. Porto Alegre, 1992, p. 499-509.

GIACOIA JUNIOR, Oswaldo. Sonhos e pesadelos da razão esclarecida: Nietzsche e a modernidade. Passo Fundo: UPF, 2005. 
GOERGEN, Pedro. Teoria da ação comunicativa e práxis pedagógica. In: Revista Espaço Pedagógico. Passo Fundo: Vol. 10, n. 1, Jan/Jun. 2003.

GOMES, Luiz Roberto. Educação e consenso em Habermas. Campinas: Editora Alínea, 2007.

HABERMAS, Jürgen. O discurso filosófico da modernidade. São Paulo: Martins Fontes, 2002.

Trabalho e interação. In: Técnica e ciência como ideologia. Lisboa: Edições 70, 2009, p. 11- 43

HEIDEGGER, Martin. Ser e Tempo - Parte I. 14a ed. Petrópolis: Vozes, 2005.

JAEHN, Lisete. Educação para a emancipação em Adorno. Passo Fundo: UPF, 2005.

KANT, Immanuel. Resposta à pergunta: Que é "Esclarecimento"?(Aufklärung). In: Textos Seletos. Trad. Floriano de Sousa Fernandes. 3a ed. Petrópolis: Editora Vozes, 2005.

Crítica da Razão Prática. Trad. Afonso Bertagnoli. 4ạ ed. Rio de Janeiro: Ediouro, sd.

LARROSA, Jorge. Nietzsche e a educação. 2a ed. Belo Horizonte: Autêntica, 2005.

MAAR, Wolfang Leo. Educação, sujeição e crítica na perspectiva de Adorno. In: DALBOSCO, Claudio Almir; TROMBETTA, Gerson Luís; LONGHI, Solange Maria. (Orgs.). Sobre filosofia e educação: subjetividade e interdiciplinaridade na fundamentação pedagógica. Passo Fundo: UPF, 2004. p. 165-184.

MARTINI, Rosa Maria Filippozzi. A questão do sujeito e o mal-estar pós-moderno: ressonâncias no contexto da educação. In: AZEVEDO, H; GHIGGI, G; OLIVEIRA, A. Interfaces: temas de educação e filosofia. Pelotas: Editora Universitária UFPEL, 2009. MARX, Karl; ENGELS, Friedrich. A Ideologia Alemã/Teses sobre Feuerbach. São Paulo: Editora Moraes, 1984.

MCCARTHY, Thomas. La Teoría Crítica de Jürgen Habermas. 3a ed. Madrid: Tecnos, 1995.

MESSER, August. História da Filosofia. Lisboa: Editorial Inquérito, 1946. 
MÜHL, Eldon Henrique. Habermas e a educação: ação pedagógica como agir comunicativo. Passo Fundo: UPF, 2003.

MÜLLER-LAUTER, Wolfang. A doutrina da vontade de poder em Nietzsche. Trad. Oswaldo Giacoia Junior. São Paulo: Annablume, 1997.

NIETZSCHE, Friedrich. Obras incompletas. In. Os Pensadores. Trad. Rubens Rodrigues Torres Filho. São Paulo: Nova Cultural, 1996.

Genealogia da Moral: uma polêmica. Trad. Paulo César de Souza. São Paulo: Companhia das Letras, 1998.

O Nascimento da tragédia: ou helenismo e pessimismo. Trad. J. Guinsburg. 2 a ed. São Paulo: Companhia das Letras, 2003.

Além do bem e do mal: prelúdio a uma filosofia do futuro. Trad. Paulo César de Souza. São Paulo: Companhia das Letras, 2005.

PINZANI, Alessandro. Habermas. Porto Alegre: Artmed, 2009.

PRESTES, Nadja Mara Hermann. Educação e racionalidade: conexões e possibilidades de uma razão comunicativa na escola. Porto Alegre: EDIPUCRS, 1996.

ROUANET, Sérgio Paulo. As razões do iluminismo. São Paulo: Companhia das Letras, 1987.

SAFRANSKI, Rüdigger. Heidegger: um mestre da Alemanha entre o bem e o mal. São Paulo: Geração Editorial, 2000.

. Nietzsche: biografia de uma tragédia. Trad. Lya Luft. São Paulo: Geração Editorial, 2001.

SARUP, Madan. Marxismo e a educação. Rio de Janeiro: Zahar Editores, 1980.

SAVIANI, Dermeval. Perspectiva marxista do problema subjetividadeintersubjetividade. In: DALBOSCO, Claudio Almir (org.). Sobre filosofia e educação: subjetividade e intersubjetividade na fundamentação da práxis pedagógica. Passo Fundo: UPF, 2004

STEIN, Ernildo. Introdução ao pensamento de Martin Heidegger. Porto Alegre: EDIPUCRS, 2002. 
TAYLOR, Charles. As Fontes do Self: A construção da identidade moderna. Trad. Adail

Ubirajara Sobral e Dinah de Abreu Azevedo. São Paulo: Editora Loyola, 1997.

VÁZQUEZ, Adolfo Sánchez. Filosofia da praxis. 2o ed. São Paulo: Expressão Popular, 2011.

WERLE, Marco Aurelio. Heidegger e a arte de questionar. In: Aprender - Caderno de Filosofia e Psicologia da Educação. Vitória da Conquista: Ano VI, no 10, 2008, p. 17-31.

ZATTI, Vicente. Autonomia e educação em Immanuel Kant e Paulo Freire. Porto Alegre: EDIPUCRS, 2007.

Disponível

em

http://www.pucrs.br/edipucrs/online/autonomiaeeducacao.pdf. Acesso em: 10 abr. 2011.

. Nietzsche e a Educação. In: OLIVEIRA, W.; SILVA, S.S.(Orgs.). Leituras em Educação - Vol. 2. São Mateus: Opção, 2008. p. 101-116.

Doutor em Educação/UFRGS Professor no Instituto Federal do Rio Grande do Sul - Campus Canoas. E-mail: vicente.zatti@canoas.ifrs.edu.br 